\title{
Predictive equations for biomass and fuel characteristics of Argentine shrubs
}

\author{
JOSE L. HIERRO, LYN C. BRANCH, DIEGO VILLARREAL, AND KENNETH L. CLARK
}

Authors are research associate, Facultad de Ciencias Exactas y Naturales (FCEN), Universidad Nacional de La Pampa (UNLPam), 6300 Santa Rosa, La Pampa, Argentina; associate professor, Department of Wildlife Ecology and Conservation and Program for Studies in Tropical Conservation, University of Florida (UF), Gainesville, Fla. 32611, U.S.A.; associate professor, FCEN, UNLPam, 6300 Santa Rosa, La Pampa, Argentina; and research associate, School of Forest Resources and Conservation, UF, Gainesville, Fla. 32611, U.S.A. At the time of the research the senior author was a graduate student in the Department of Wildlife Ecology and Conservation, University of Florida.

\section{Abstract}

Predictive equations for estimating shrub biomass in semi-arid scrub ecosystems are essential for evaluating shrub encroachment, conducting ecosystem-level studies of net primary productivity (NPP) and nutrient cycling, and examining effects of different fire regimes. In this study, we developed predictive equations to estimate total aboveground biomass and biomass of foliage and stems of the 8 most common shrubs in the semi-arid scrub (Monte) of central Argentina. We also examined the relationship between shrub size and proportions of these components for the dominant species, Larrea divaricata Cavanilles (creosotebush), and determined fuel characteristics (dead-to-live ratio, bulk density) of the 8 shrub species. Regression analyses were used to examine the relationships between aboveground biomass and 5 field measurements (diameter of the longest stem, shrub height, maximum crown width, crown width at right angles to maximum crown width, and crown volume). A natural log-log model based on a single variable best described this relationship in most cases. The easiest field measurement for 6 of the 8 species was diameter of the longest stem, and this measure was often the best predictor of shrub biomass. As L. divaricata increased in size, the proportional biomass of large stems increased, and biomass of foliage and small stems decreased. This pattern suggests productivity may decrease with shrub age. The mass of dead material was low in most shrub species. Bulk densities were comparable to those of shrubs in other semi-arid ecosystems. Equations developed here will allow rapid and accurate estimation of shrub biomass in the Monte of Argentina.

Key Words: Semi-arid scrub, Larrea, shrub biomass, Monte, Argentina

Research was funded in part by UNL Pam, Rotary Foundation, Conservation, Food, and Health Foundation, Fulbright-LASPAU Program, and the Compton Foundation. Authors wish to thank Facultad de Agronomia and FCEN of UNLPam, the Norlander family, and M. Romero for logistical support. We gratefully acknowledge the field assistance of M. Machicote, G. Jgarzabal, C. Wander, V. Hochman, R. Serracin, L. Caviglia, F. Tello Lambrecht, and A. Belaus. We especially thank W. Muiflo for field and lab assistance. H. Troiani and P. Steibel provided us with an update on scientific nomenclature and G. Alfonso provided key information on Monte in Argentina. Three anonymous reviewers provided helpful comments on the manuscript. This is Florida Agricultural Experiment Station Journal Series No. R-07100.

Manuscript accepted 7 Mar. 2000.

\section{Resumen}

Las ecuaciones predictivas para estimar la biomasa de arbustos en ecosistemas semiáridos son esenciales para evaluar incrementos en la densidad de arbustos, para conducir estudios de productividad primaria neta (PPN) y ciclo de nutrientes y para examinar los efectos de diferentes regímenes de fuego. En este estudio se desarrollaron ecuaciones predictivas para estimar biomasa aérea total y biomasa de hojas y ramas de las 8 especies de arbustos más comunes en el arbustal semiárido (Monte) del centro de Argentina. También se examinó la relación entre el tamaño del arbusto y la proporción de cada uno de estos componentes en la especie dominante, Larrea divaricata Cavanilles (jarilla), y se determinaron característcas combustibles (proporción de muerto a vivo, densidad de la corona) en las 8 especies. La relación entre biomasa aérea y 5 medidas tomadas en el campo a los arbustos (diámetro de la rama más larga, altura, ancho máximo de la corona, ancho perpendicular al ancho máximo y volumen) fue evaluada mediante el uso de análisis de regresión. En la mayoría de los casos, el modelo logarítmico natural con una sola variable fue el que mejor describió esta relación. La medida más fácil de tomar en el campo en 6 de las 8 especies fue el diámetro de la rama más larga, la que frecuentemente fue la que mejor predijo la biomasa de los arbustos. El aumento en tamaño de $L$. divaricata fue acompañado por un aumento en la proporción de biomasa aportada por las ramas grandes, y por un descenso en la proporción de biomasa aportada por hojas y ramas pequeñas. Este patrón sugiere que la productividad de los arbustos decrecería con la edad. La cantidad de material muerto fue escasa en la mayoría de las especies. La densidad de la corona de los arbustos fue comparable a la de arbustos en otros ecosistemas semiáridos. Las ecuaciones desarrolladas aquí permitirán una estimación rápida y precisa de la biomasa de arbustos en el Monte de Argentina.

Shrubs are a major component of vegetation in semi-arid ecosystems worldwide, and their ability to dominate these systems is a matter of ecological and economic concern (Schlesinger et al. 1990). Predictive equations for estimating shrub biomass from relatively simple morphometric data collected in the field have been developed for shrubs in a variety of ecosystems (see Etienne 1989, Catchpole and Wheeler 1992 for reviews), but are generally lacking for the semi-arid Monte of Argentina (Braun et al. 1979). This ecosystem is similar to creosotebush [Larrea tri dentata (Sesse \& Moc. cx DC) Cov.]-dominated regions in North 
America, and covers an area of 600,000 $\mathrm{km}^{2}$, or about $16 \%$ of Argentina (Ragonese 1967). Reliable equations to estimate woody vegetation biomass are needed for evaluating rates of shrub encroachment, for estimating fuel loads for fire models and evaluating effects of various fire management regimes, as well as for ecosystem-level studies of net primary productivity (NPP) and nutrient cycling.

Our research had 3 objectives: 1) to develop predictive equations to estimate total aboveground biomass, as well as biomass of foliage and stems (grouped by diameter class) of the 8 most common shrubs in Monte of central Argentina; 2) examine the relationship between shrub size and relative proportions of components (foliage and stems) for the dominant species, Larrea divaricata Cavanilles (creosotebush); and 3) determine fuel characteristics (dead-to-live ratio and bulk density, i.e., biomass per unit volume occupied by biomass and air) of these 8 species.

\section{Materials and Methods}

\section{Study Area}

Shrubs were collected at Los Ranqueles Ranch (18,000 ha) located $15 \mathrm{~km}$ E of Lihue Calel National Park $\left(38^{\circ} 00^{\prime} \mathrm{S}, 65^{\circ}\right.$ $00^{\prime} \mathrm{W}$ ) in La Pampa province, Argentina. The climate is characterized by hot summers, cool winters, and low, unpredictable rainfall (mean annual precipitation from 1983 to 1993 was $524 \pm 175 \mathrm{~mm}$ (Dirección de Estadistica y Censos 1981, 1991, Lihue Calel National Park, unpubl. data). The vegetation consists of a mosaic of shrub patches and open areas. L. divari cata generally comprises $80-90 \%$ of the shrub biomass; other less abundant shrubs include L. cunefolia Cavanilles (jarilla macho), Condalia microphylla Cavanilles (piquillín), Geoffroea decorticans (Gill ex Hook. et Arnott) Burkart (chañar), and Prosopis flexuosa DC var. depressa F.A.
Roig (alpataco dulce) (Instituto Nacional de Tecnologia Agropecuaria 1980). Open areas and the understory below shrubs consist of subshrubs [e.g., Acantholipia seriphioides (A. Gray) Moldenke (tomillo), Senna aphylla (Cay.) Irwin \& Barneby (pichanilla)], grasses (e.g., Stipa spp.), and herbs [e.g., Medicago minima (L.) Grufberg (trébol de carretilla), Erodium cicutarum (L.) L'Herit. Ex Ait. (alfilerillo), and Baccharis spp.].

\section{Shrub Sampling}

Shrubs of Chuquiraga erinacea Don (chilladora), C. microphylla, G. decorti cans, L. cuneifolia, L. divaricata, L. nitida Cavanilles (jarilla crespa), and P. flexuosa var. depressa were sampled during the period of maximum leaf area (late spring to early autumn) of 1993-1994 and 1994-1995. Individual plants were selected to encompass a range of heights and canopy forms observed in the field (Table 1). Saplings (individuals $\leq 3.20$-in height) of the tree Prosopis caldenia Burkart (caldén) were also collected and treated as shrubs in this analysis. All shrubs were measured for: 1) diameter of the longest stem at $10 \mathrm{~cm}$ above the ground (dls) to the nearest) $0.05 \mathrm{~mm}$ using a caliper, 2) height from ground level to the tallest living tissue (h) to the nearest $5 \mathrm{~cm}, 3$ ) maximum crown width (mcw) to the nearest 5 $\mathrm{cm}$, and 4) crown width at right angles to mcw (cw90) to the nearest $5 \mathrm{~cm}$. Shrubs were then cut at ground level and placed in separate bags. Diameter of the longest stem was not measured in C. microphylla or P. flexuosa var. depressa because the canopy structure and abundant thorns of these species made it difficult and unpractical to measure.

All shrubs were transported to the laboratory, dried at $65^{\circ} \mathrm{C}$ to a constant weight, and weighed to determine total biomass. A representative sample of each individual (about $25 \%$ ) was selected and separated into foliage and live and dead stems. Stems were further divided into diameter classes representing standard time lags for equilibrating fuel moisture models as follows: <6 mm (1 hour), 6-25 mm (10 hrs), $>25-76 \mathrm{~mm}$ (100 hrs) (Fosberg 1970, Rothermel 1972, Kessel et al. 1978, Pereira et al. 1995). All components were then weighed separately.

\section{Data Analysis}

Biomass of each component was calculated by multiplying the proportion of each component in the subsample by the total biomass of each shrub. Crown volume (vol) was calculated using the formula for the solid object that best fits the natural shape of each shrub species (Ludwig et al. 1975, Murray and Jacobson 1982, Molinero 1983, Etienne 1989) as follows: Larrea spp., P. caldenia, G. decorticans, and $C$. erinacea, inverted cone $\left[\pi / 3 \mathrm{R}^{2} \mathrm{~h}\right.$, where $\mathrm{R}=$ radius, calculated as $(\mathrm{mcw}+$ cw90)/4]; C. microphylla, upper half of a spheroid (4/3 $\left.\pi \mathrm{R}^{2} \mathrm{~h}\right)$; P. flexuosa var. depressa, upper half of a prolate spheroid (4/3 $\pi$ mcw cw90h).

Regression analyses were conducted with the statistical package SPSS (SPSS Inc. 1996) to examine the relationship between total aboveground biomass, and the bioinass of each component and each of the field measurements (dls, h, mcw, cw90 and vol). The following linear models were evaluated: 1$)$ simple linear $(\mathrm{y}=\mathrm{b}$ $\mathrm{x}$ and $\mathrm{y} a+\mathrm{b} \mathrm{x})$; 2) natural logarithmic (y $=\mathrm{a}+\mathrm{b} \ln (\mathrm{x}))$; 3) natural $\log -\log (\ln (\mathrm{y})=$ $\ln (\mathrm{a})+\mathrm{b} \ln (\mathrm{x})) ; 4)$ exponential $(\ln (\mathrm{y})=$ $\ln (\mathrm{a})+\mathrm{bx})$; and 5) multiple regression (y $=\mathrm{a}+\mathrm{b}_{1} \mathrm{x}_{1}+\mathrm{b}_{2} \mathrm{x}_{2}$ and $\ln (\mathrm{y})=\ln (\mathrm{a})+$ $\left.\mathrm{b}_{1} \ln \left(\mathrm{x}_{1}\right)+\mathrm{b}_{2} \ln \left(\mathrm{x}_{2}\right)\right)$. The best models for each species were selected based on the maximum values of the coefficients of determination $\left(\mathrm{r}^{2}\right)$ and standard errors of the estimate $\left(\mathrm{S}_{\mathrm{y}, \mathrm{x}}\right)$. When more than 1 model presented similarly good fit to the data, the regression equation with the fewest parameters was chosen as the best model.

Although logarithmic models often are used to predict biomass of shrubs from

Table 1. Number of individuals, ranges of measurements [dry weight (w), volume ${ }^{1}$ (vol.), and height (h)] and mean values \pm SE of bulk density ( $\left.\psi_{\mathbf{b}}\right)$ and dead to live ratio (dl) of each species.

\begin{tabular}{|c|c|c|c|c|c|c|}
\hline Species & $\mathrm{n}$ & $\mathrm{w}$ & vol & $\mathrm{h}$ & $\psi_{\mathrm{b}}$ & $\mathrm{d} / 1$ \\
\hline & & (g) & $\left(\mathrm{ms}^{3}\right)$ & (m) & $\left(\mathrm{g} \mathrm{m}^{-3}\right)$ & \\
\hline C. erinacea & 10 & $90.5-5026.2$ & $0.02-1.09$ & $0.40-1.10$ & $4955.4 \pm 400.9$ & $0.02 \pm 0.01$ \\
\hline C. microphylla & 15 & $25.8-41326.1$ & $0.02-43.28$ & $0.20-2.40$ & $1785.0 \pm 163.8$ & $0.02 \pm 0.01$ \\
\hline L. cunefolia & 15 & $17.6-10503.7$ & $0.02-5.79$ & $0.40-2.30$ & $2285.8 \pm 224.1$ & $0.01 \pm 0.00$ \\
\hline L. divaricata & 30 & $63.4-24085.0$ & $0.03-20.17$ & $0.55-3.30$ & $1324.1 \pm 77.9$ & $0.01 \pm 0.00$ \\
\hline L. nitida & 15 & $49.4-31923.3$ & $0.03-16.83$ & $0.45-2.85$ & $1671.2 \pm 100.5$ & $0.04 \pm 0.01$ \\
\hline
\end{tabular}


Table 2. Best fit linear equations and power equations for predicting total aboveground biomass, foliage biomass, and biomass of stems by diameter class $(<6,6-25,>25 \mathrm{~mm})$ for 8 woody species. $S_{y . x}=$ standard error of the estimate for linear equations (Sy.xl), back-transformed values from log$\log$ models $(S y . x 2)$, and power equations $\left(S_{y . x 3}\right) ; r^{2}=$ coefficient of determination for linear equations $\left(r_{1}{ }^{2}\right)$ and power equations $\left(r_{2}{ }^{2}\right) ; w^{2}=d_{r y}$ weight $(\mathrm{g})$; vol = volume $\left(\mathrm{m}^{3}\right)$; dls = diameter of the longest $\mathrm{stem}$ at $10-\mathrm{cm}$ height $(\mathrm{mm})$; mew = maximum crown width $(\mathrm{m})$; cw90 = crown width at right angles to $\mathrm{mcw}(\mathrm{m}) ; \mathbf{h}=$ height $(\mathrm{m}) ; \mathrm{ln}=$ natural log. Total biomass equations using dls are presented for all species in which this variable was measured, even though this was not always the best predictor, because dls is the easiest variable to measure and is a good predictor of biomass. All models are significant at $\mathrm{p}<\mathbf{0 . 0 0 5}$.

\begin{tabular}{|c|c|c|c|c|c|c|c|c|c|}
\hline Species & $\mathrm{n}$ & Biomass & Best fit linear equation & $\mathrm{S}_{\mathrm{y} \cdot \mathrm{xl}}$ & $\mathrm{S}_{\mathrm{y} \cdot \mathrm{x} 2}$ & $\mathrm{r}_{1}^{2}$ & Power equation & $\mathrm{S}_{\mathrm{y} \cdot \mathrm{x} 3}$ & $r_{2}^{2}$ \\
\hline \multirow[t]{5}{*}{ C. erinacea } & 10 & Total & $\ln (w)=6.55+2.55 \operatorname{lnmcw})$ & 0.28 & 513.66 & 0.95 & $\mathrm{w}=786.93 \mathrm{mcw}^{2.31}$ & 502.03 & 0.91 \\
\hline & & & $\ln (\mathrm{w})=1.11+2.21 \ln (\mathrm{dls})$ & 0.84 & 1084.83 & 0.56 & $\mathrm{w}=30.99 \mathrm{dls}^{1.46}$ & 922.66 & 0.68 \\
\hline & 10 & Leaves & $\ln (w)=6.80+0.96 \ln (\mathrm{mcw})$ & 0.29 & 286.87 & 0.84 & $\mathrm{w}=899.47 \mathrm{mcs}^{1.04}$ & 281.63 & 0.80 \\
\hline & 10 & $<6 \mathrm{~mm}$ & $\ln (w)=5.70+1.34 \ln (\mathrm{cw} 90)$ & 0.32 & 103.10 & 0.92 & $\mathrm{w}=292.70 \mathrm{cw} 90^{1.44}$ & 103.28 & 0.81 \\
\hline & 10 & $6-25 \mathrm{~mm}$ & $\ln (w)=7.58+0.90 \ln (\mathrm{vol})$ & 0.41 & 166.61 & 0.95 & $\mathrm{w}=1982.46 \mathrm{vol}^{0.92}$ & 165.59 & 0.95 \\
\hline \multirow[t]{5}{*}{ C. microphylla } & 15 & Total & $\ln (w)=6.77+2.93 \ln (\mathrm{mcw})$ & 0.29 & 5592.90 & 0.98 & $\mathrm{w}=1692.02 \mathrm{mcw}^{2.24}$ & 2374.36 & 0.96 \\
\hline & 15 & Leaves & $\ln (w)=5.04+2.19 \ln (\mathrm{mcw})$ & 0.23 & 162.74 & 0.98 & $\mathrm{w}=116.42 \mathrm{mcw}^{2.43}$ & 160.62 & 0.98 \\
\hline & 15 & $<6 \mathrm{~mm}$ & $\ln (w)=6.39+2.40 \ln (\mathrm{cw} 90)$ & 0.35 & 572.30 & 0.95 & $\mathrm{w}=342.58 \mathrm{cw} 90^{2.82}$ & 345.65 & 0.99 \\
\hline & 15 & $6-25 \mathrm{~mm}$ & $w=-2448.99+3578.03 \mathrm{cw} 90$ & 653.98 & & 0.96 & & & \\
\hline & 8 & $>25 \mathrm{~mm}$ & $w=-2086.53+2426.38 \mathrm{cw} 90$ & 510.56 & & 0.96 & & & \\
\hline \multirow[t]{5}{*}{ G. decorticans } & 15 & Total & $\ln (w)=-2.15+2.64 \ln (\mathrm{dls})$ & 0.32 & 886.67 & 0.98 & $\mathrm{w}=0.41 \mathrm{dls} \mathrm{s}^{2.31}$ & 406.15 & 0.99 \\
\hline & 15 & Leaves & $\ln (w)=3.71+2.60 \ln (h)$ & 0.46 & 51.20 & 0.92 & $\mathrm{w}=43.27 \mathrm{~h}^{2.65}$ & 42.63 & 0.97 \\
\hline & 15 & $<6 \mathrm{~mm}$ & $\ln (w)=5.15+2.80 \ln (h)$ & 0.33 & 577.41 & 0.96 & $\mathrm{w}=318.40 \mathrm{~h}^{1.80}$ & 283.82 & 0.86 \\
\hline & 15 & $6-25 \mathrm{~mm}$ & $\ln (w)=-4.17+2.96 \ln (\mathrm{dls})$ & 0.24 & 348.83 & 0.99 & $\mathrm{w}=0.07 \mathrm{dls}^{2.58}$ & 276.72 & 0.96 \\
\hline & 8 & $>25 \mathrm{~mm}$ & $\ln (w)=6.99+0.90 \ln (\mathrm{vol})$ & 0.29 & 428.87 & 0.92 & $\mathrm{w}=1149.97 \mathrm{vol}^{0.65}$ & 360.00 & 0.79 \\
\hline \multirow[t]{4}{*}{ L. cuneifolia } & 15 & Total & $\ln (w)=-0.60+2.72 \ln (\mathrm{dls})$ & 0.47 & 1804.25 & 0.93 & $\mathrm{w}=6.73 \mathrm{dls}^{1.94}$ & 613.85 & 0.95 \\
\hline & 15 & Leaves & $\ln (w)=5.69+0.60 \ln (\mathrm{vol})$ & 0.33 & 135.93 & 0.93 & $\mathrm{w}=233.83 \mathrm{vol}^{0.81}$ & 79.11 & 0.97 \\
\hline & 15 & $<6 \mathrm{~mm}$ & $\ln (w)=6.45+0.77 \ln (\mathrm{vol})$ & 0.36 & 367.91 & 0.95 & $\mathrm{w}=677.67 \mathrm{vol}^{0.63}$ & 219.63 & 0.94 \\
\hline & 14 & $6-25 \mathrm{~mm}$ & $\ln (w)=7.05+1.16 \ln (\mathrm{vol})$ & 0.53 & 3024.72 & 0.95 & $\mathrm{w}=1670.55 \mathrm{vol}^{0.70}$ & 372.93 & 0.98 \\
\hline \multirow[t]{6}{*}{ L. divaricata } & 30 & Total & $\ln (w)=7.19+0.93 \ln (\mathrm{vol})$ & 0.32 & 2423.82 & 0.96 & $\mathrm{w}=1410.32 \mathrm{vol}^{0.94}$ & 2307.43 & 0.87 \\
\hline & & & $\ln (w)=-0.72+2.71 \ln (\mathrm{dls})$ & 0.44 & 3731.82 & 0.93 & $\mathrm{w}=6.11 \mathrm{dls}^{2.03}$ & 3509.81 & 0.70 \\
\hline & 30 & Leaves & $\ln (w)=4.40+1.68 \ln (\mathrm{cw} 90)$ & 0.54 & 211.19 & 0.83 & $\mathrm{w}=88.51 \mathrm{cw} 90^{1.77}$ & 200.89 & 0.66 \\
\hline & 30 & $<6 \mathrm{~mm}$ & $\ln (w)=5.37+1.93 \ln (\mathrm{cw} 90)$ & 0.43 & 419.71 & 0.91 & $\mathrm{w}=285.02 \mathrm{cw} 90^{1.61}$ & 405.18 & 0.76 \\
\hline & 29 & $6-25 \mathrm{~mm}$ & $\ln (w)=6.49+1.24 \ln (\mathrm{vol})$ & 0.43 & 1036.75 & 0.96 & $\mathrm{w}=764.32 \mathrm{vol}^{1.11}$ & 1142.68 & 0.89 \\
\hline & 11 & $>25 \mathrm{~mm}$ & $\ln (w)=5.03+1.15 \ln (\mathrm{vol})$ & 0.65 & 794.16 & 0.62 & $\mathrm{w}=70.43 \mathrm{vol}^{1.60}$ & 607.11 & 0.80 \\
\hline \multirow[t]{5}{*}{ L. nitida } & 15 & Total & $\ln (w)=7.39+0.99 \ln (\mathrm{vol})$ & 0.26 & 3221.38 & 0.99 & $\mathrm{w}=12.14 \mathrm{vol}^{2.74}$ & 4185.39 & 0.77 \\
\hline & 15 & Total & $\ln (w)=-0.76+2.77 \ln (\mathrm{dls})$ & 0.60 & 2676.48 & 0.92 & $\mathrm{w}=0.30 \mathrm{dls}^{2.85}$ & 2203.00 & 0.94 \\
\hline & 15 & Leaves & $\ln (w)=4.46+1.97 \ln (\mathrm{mcw})$ & 0.50 & 131.24 & 0.85 & $\mathrm{~W}=89.61 \mathrm{MCW}^{1.95}$ & 130.54 & 0.91 \\
\hline & 15 & $<6 \mathrm{MM}$ & $\ln (w)=6.18+0.83 \ln (\mathrm{vol})$ & 0.29 & 270.20 & 0.96 & $\mathrm{w}=386.34 \mathrm{vol}^{0.83}$ & 141.11 & 0.96 \\
\hline & 15 & $6-25 \mathrm{~mm}$ & $\ln (w)=6.86+1.30 \ln (\mathrm{vol})$ & 0.40 & 2451.62 & 0.97 & $\mathrm{w}=1389.00 \mathrm{vol}^{0.88}$ & 380.75 & 0.98 \\
\hline \multirow[t]{5}{*}{ P. caldenia } & 15 & Total & $\ln (w)=-0.43+2.18 \ln (\mathrm{dls})$ & 0.28 & 1200.28 & 0.97 & $\mathrm{w}=0.08 \mathrm{dls}^{2.68}$ & 1030.40 & 0.93 \\
\hline & 15 & Leaves & $\ln (w)=5.27+0.88 \ln (\mathrm{vol})$ & 0.33 & 67.64 & 0.94 & $\mathrm{w}=219.94 \mathrm{vol}^{0.84}$ & 62.89 & 0.89 \\
\hline & 15 & $<6 \mathrm{~mm}$ & $\ln (\mathrm{w})+-0.32+1.85 \ln (\mathrm{dls})$ & 0.27 & 267.93 & 0.96 & $\mathrm{w}=106 \mathrm{dls}^{1.76}$ & 267.85 & 0.85 \\
\hline & 14 & $6-25 \mathrm{~mm}$ & $\ln (w)=5.84+2.85 \ln (\mathrm{cw} 90)$ & 0.41 & 517.63 & 0.93 & $\mathrm{w}=220.83 \mathrm{cw} 90^{3.78}$ & 412.51 & 0.89 \\
\hline & 8 & $>25 \mathrm{~mm}$ & $\ln (w)=5.75+1.98 \ln (\mathrm{vol})$ & 0.45 & 288.08 & 0.87 & $\mathrm{w}=373.91 \mathrm{vol}^{1.75}$ & 238.78 & 0.96 \\
\hline P. flexuosa & 15 & Total & $\ln (w)=6.24+2.63 \ln (\mathrm{cw} 90)$ & 0.32 & 2313.61 & 0.96 & $\mathrm{w}=208.02 \mathrm{cw} 90^{3.60}$ & 1893.13 & 0.88 \\
\hline \multirow[t]{3}{*}{ var. depressa } & 15 & Leaves & $\ln (\mathrm{w})=3.19+0.85 \ln (\mathrm{vol})$ & 0.40 & 160.33 & 0.95 & $\mathrm{w}=61.99 \mathrm{vol}^{0.61}$ & 117.51 & 0.91 \\
\hline & 15 & $<6 \mathrm{~mm}$ & $\ln (w)=4.52+0.98 \ln (\mathrm{vol})$ & 0.27 & 1240.57 & 0.98 & $\mathrm{w}=70.91 \mathrm{vol}^{0.99}$ & 1009.05 & 0.87 \\
\hline & 12 & $6-25 \mathrm{~mm}$ & $\ln (\mathrm{w})=5.16+1.98 \ln (\mathrm{mcw})+3.25 \ln (\mathrm{h})$ & 0.59 & 0.94 & & & & \\
\hline
\end{tabular}

other morphometric data (Murray and Jacobson 1982, Hughes et al. 1987, Pereira et al. 1995), log-antilog transformations sometimes can result in biased estimates of biomass (Tausch and Tueller 1988). Therefore, where a logarithmic model was selected as the best model, we also present the corresponding nonlinear model, and compare the standard error of the estimate from this model with the standard error of the estimate calculated using back-transformed estimates from the logarithmic model. For these comparisons, predicted biomass from the logarithmic equation was converted to the arithmetic form (anti-log) and the standard error was computed using actual biomass and the corresponding predicted biomass. Regressions were not performed on the component of stems $>25 \mathrm{~mm}$ for $L$. cuneifolia, L. nitida, C. erinacea, and $P$. flexuosa var. depressa because only a few individual plants of these species had large stems ( $\mathrm{n}=5,4,2$, and 0 , respectively).

For L. divaricata, the relationships between total biomass and relative proportions of the various components (leaves, stems < $6 \mathrm{~mm}$, stems $6-25 \mathrm{~mm}$, stems > $25 \mathrm{~mm}$ ) were examined using best fit nonlinear models. The model with the highest $r^{2}$ was selected for graphical presentation.

Dry weight and volume of total aboveground biomass were used to calculate bulk density for each species. Packing ratio, the ratio between bulk density and specific gravity (i.e., biomass per unit volume occupied by the biomass alone), is commonly used to describe the compactness of fuel (Rothermel 1972, Van Wilgen et al. 1990, Pereira et al. 1995). In fire models, specific gravity is usually considered a constant (Rotherinel 1972); thus, bulk density is the primary variable that determines compactness (Brown 1981).

\section{Results and Discussion}

For all shrub species, at least 1 of the morphological measurements was a good predictor of total aboveground biomass, as 


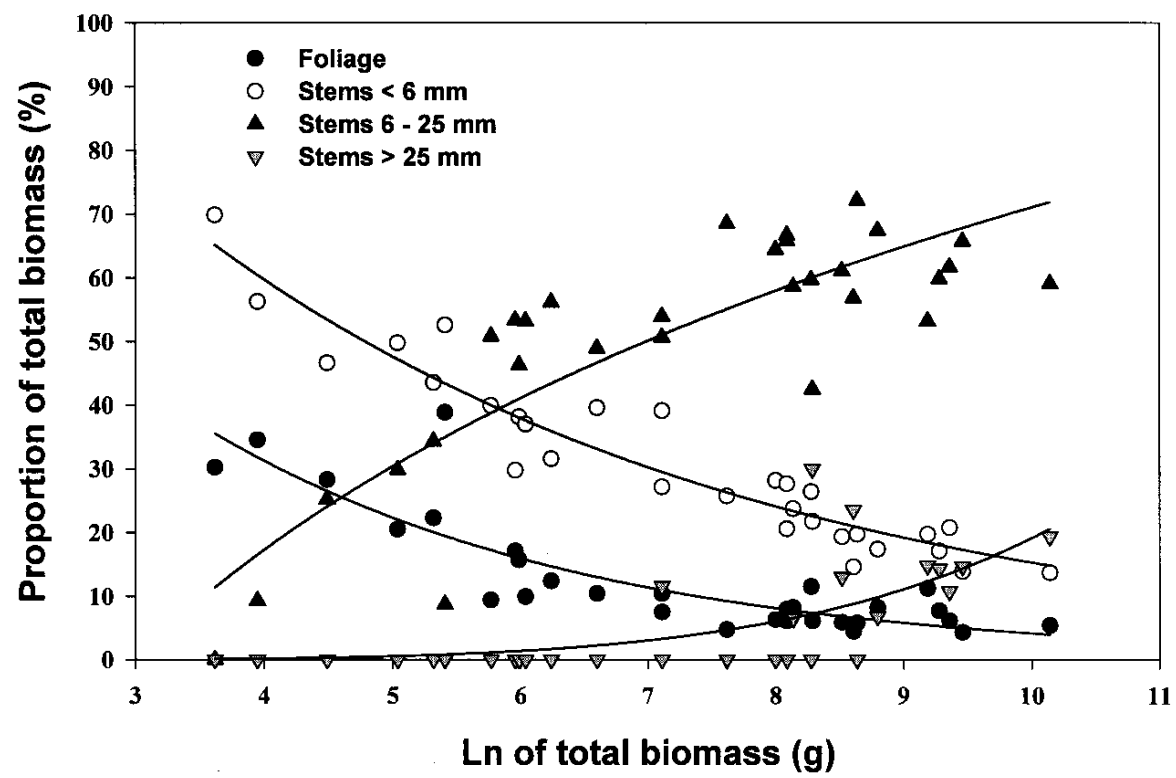

Fig. 1. Proportional biomass of foliage and stems as a function of total biomass of $L$. divarica ta $(\mathrm{n}=30)$. Foliage $\left(\mathrm{y}=120.76 \mathrm{e}^{0.34 \mathrm{x}}, \mathrm{r}^{2}=0.75\right)$; stems $<6 \mathrm{~mm}$ diameter $\left(\mathrm{y}=148.38 \mathrm{e}^{-0.23 \mathrm{x}}\right.$, $\left.r^{2}=0.90\right)$; stems 6-25 mm diameter $\left(y=-64.15+58.69 \ln (x), r^{2}=0.73\right)$; stems $>25 \mathrm{~mm}$ diameter $\left(y=0.001 x^{5.20}, r^{2}=0.44\right)$. Ln = natural $\log$. All models are significant at $p<$ 0.0001.

well as the biomass of each component (Table 2). Predictive equations developed using a single independent variable had a better fit to the data when compared to equations using 2 independent variables in all but 1 case $(6-25 \mathrm{~mm}$ stems of $P$ flexu osa var. depressa). The easiest field measurement to make for 6 of the species was diameter of the longest stem, and equations for total aboveground biomass using this variable had a good fit to the data except for $C$. erinacea (Table 2).

In most cases, a natural log-log model gave the best fit between field measurements and total aboveground bioinass, and between field measurements and bioinass of components for linear models (Table 2), similar to results reported in other studies (Brown 1976, Ohmann et al. 1976, Murray and Jacobson 1982, Rittenhouse and Sneva 1977, Braun et al. 1979, Bryant and Kothmann 1979 Hughes et al. 1987, Pereira et al. 1995). In all species except L. nitida, standard errors of the estimate computed from power equations were lower than those calculated using backtransformations from log-log regression. Coefficients of determination generally were high for both log-log and power equations. In view of the potential for bias in predicting biomass from equations developed with transformed data (Sprugel 1983), power equations provide a good alternative to $\log -\log$ equations for the shrub species in our study.

The plot of total aboveground bioinass vs the proportion of biomass components for L. divaricata (Fig. 1) indicates that as shrubs grow, the proportions of foliage and stems $<6 \mathrm{~mm}$ decrease, while the proportions of stems of 6-25 mm diameter and larger increase. If carbon respired by live stem tissue represents an increasingly larger amount of carbon fixed in foliage by photosynthesis, then productivity of shrubs should decrease with age. This age/productivity relationship is well known for trees in a variety of ecosystems (Ryan et al. 1997, Carey et al. 1998), but it is poorly documented for shrubs.

$C$. erinacea and $G$. decorticans had the highest bulk densities, Larrea spp., $P$. caldenia, and $C$. microphylla were intermediate, and $P$. flexuosa var. depressa had a much lower bulk density (Table 1 ). With the exception of P. flexuosa var. depressa, are comparable to those of shrubs in other fire-prone ecosystems (Van Wilgen et al. 1990, Pereira et al. 1995). Dead material was a small component of total aboveground biomass of the shrubs examined; the maximum mean value was $17 \%$ dead material for P. flexuosa var. depressa (Table 1). For all species, stems $<6 \mathrm{~mm}$ diameter represented most of the dead material [e.g., $90.8 \pm 5.4 \%$ for $P$. flexuosa var. depressa].

As in North America, livestock ranching is the predominant land use in creosotebushdominated ecosystems in Argentina. bulk densities of shrubs in our study area
Overgrazing in semi-arid ecosystems in North America has favored shrubs over herbaceous vegetation (Schlesinger et al. 1990). The impacts of livestock grazing in Argentine Monte have not been assessed, but similar patterns may occur. Fire is an important natural component of these ecosystems, and is used extensively as a management tool to control shrubs. The predictive equations for biomass developed in this study will allow rapid and accurate estimation of shrub biomass in the Monte of Argentina. This information is essential for monitoring the effects of grazing on shrub dynamics, for examining the impacts of different fire regimes on the aboveground bioinass of shrubs, and for studies of ecosystem productivity.

\section{Literature Cited}

Braun, R.H., R.J. Candia, R. Leiva, M.N. Páiez, C.R. Stasi, and C.F. Wuilloud. 1979. Productividad primaria area neta del Algarrobal de Nacufian (Mendoza). Deserta 5:7-39.

Brown, J.K. 1976. Estimating shrub biomass from basal stem diameters. Can. J. Forest Res. 6:153-158.

Brown, J.K. 1981. Bulk densities of nonuniform surface fuels and their application to fire modeling. Forest Sci. 27:667-683.

Bryant, F. and M. Kothmann. 1979. Variability in predicting edible browse from crown volume. J. Range Manage. 32:144-146.

Carey, E.V., R.M. Callaway, and E.H. DeLucia. 1998. Increased photosynthesis offsets costs of allocation to sapwood in an arid environment. Ecol. 79:2281-2291.

Catchpole, W.R. and C.J. Wheeler. 1992. Estimating plant biomass: A review of techniques. Aust. J. Ecol. 17:121-131.

Dirección de Estadistica y Censos. 1981. Lluvias 1921-1980. Dirección de estadistica y censos. Santa Rosa, La Pampa, Argentina.

Dirección de Estadistica y Censos. 1991. Lluvias registradas en la provincia de $\mathrm{La}$ Pampa. Dirección de estadistica y censos. Santa Rosa, La Pampa, Argentina.

Etienne, M. 1989. Non destructive methods for evaluating shrub bioinass: a review. Acta Oecologica/Oecologia Applicata 10:115-128.

Fosberg, M.A. 1970. Drying rates of heartwood below fiber saturation. Forest Sci. 16:57-63.

Hughes, G., L. Varner, and L. Blankeship. 1987. Estimating shrub production from plant dimensions. J. Range Manage. 40:367-369.

Instituto Nacional de Tecnologia Agropecuaria. 1980. Inventario integrado de los recursos naturales de la provincia de $\mathrm{La}$ Pampa. Instituto Nacional de Tecnologia Agropecuaria, Buenos Aires, Argentina. 
Kessel, S.R., M.W. Potter, C.D. Bevins, L.Bradshaw, and B.W. Jeske. 1978. Analysis and application of forest fuel data. Environ. Manage. 2:347-363.

Ludwig, J., J. Reynolds, and P. Whitson. 1975. Size-biomass relationships of several Chihuahuan desert shrubs. Amer. Midland Natur. 94:451-461.

Molinero, H. 1983. Técnicas de determinación de bioinasa de cinco especies de arbustos. Taller Sobre Arbustos Forraj eros de Zonas Aridas y Seini ridas, Mendoza, 7-9 Sept. $31-41$.

Murray, R. and M. Jacobson. 1982. An evaluation of dimension analysis for predicting shrub bioinass. J. Range Manage. 35:451-454.

Obmaun, L., D. Grigal, and R. Brander. 1976. Biomass estimation for five shrubs from northeastern Minnesota. USDA Forest Serv. Res. Note NC 133.
Pereira, J.M.C., N.M.S. Sequeira, and M.B. Carreiras. 1995. Structural properties and dimensional relations of some Mediterranean shrub fuels. Int. J. Wildl. Fire 5:35-42.

Ragonese, A.E. 1967. Vegetación y ganaderia en la Repiiblica Argentina. Colección Cientifica del INTA. Buenos Aires.

Rittenhouse, L.R. and F.A. Sneva. 1977. A technique for estimating big sagebrush production. J. Range Manage. 30:68-70.

Rothermel, R.C. 1972. A mathematical model for predicting fire spread in wildland fuels. USDA For. Serv. Res. Paper INT-30. Intermountain For. and Range Exp. Sta.

Ryan, M.G., D. Binkley, and J.H. Fownes. 1997. Age-related decline in forest productivity: pattern and process. Advan. Ecol. Res. $17: 213-262$
Schlesinger, W.H., J.F. Reynolds, G.L. Cunningham, L.F. Huenneke, W.M. Jarrell, R.A., Virginia, and W.G. Whitford. 1990. Biological feedbacks in global desertification. Sci. 247:1043-1048.

Sprugel, D.G. 1983. Correcting for bias in logtransformed allometric equations. Ecol. 64:209-210.

SPSS Inc. 1996. Base 7.0 for windows user's guide. SPSS Inc., Chicago, Ill.

Tausch, R.J. and P.T. Tueller. 1988. Comparison of regression methods for predicting singleleaf pinyon phytomass. Great Basin Natur. 48:39-45.

Van Wilgen, B.W., K.B. Higgins, and D.U. Bellstedt. 1990. The role of vegetation structure and fuel chemistry in excluding fire from forest patches in the fire-prone fynbos shrublands of So. Africa. J. Ecol. 78:210-222. 